\title{
Improved Photovoltaic Response of a Near-Infrared Sensitive Solar Cell by a Morphology-Controlling Seed Layer
}

\author{
Lushuai Zhang, ${ }^{\dagger}$ Trisha L. Andrew ${ }^{\dagger}{ }^{\dagger} *$
}

\author{
${ }^{[\dagger]}$ Department of Materials Science and Engineering, University of Wisconsin-Madison, \\ Madison, Wisconsin 53706 \\ ${ }^{[\S]}$ Department of Chemistry, University of Wisconsin-Madison, Madison, Wisconsin 53706 \\ ${ }^{[*]}$ tandrew@chem.wisc.edu
}




\begin{abstract}
We demonstrate that a thin seed layer of indium phthalocyanine chloride (ClInPc) annealed under mild conditions effectively controls the morphology of both post-annealing deposited ClInPc films and ClInPc: $\mathrm{C}_{60}$ mixed films, introducing the triclinic phase into the commonly monoclinic phase dominating film. $\mathrm{ClInPc} / \mathrm{C}_{60}$ planar solar cells and $\mathrm{ClInPc}_{6} \mathrm{C}_{60}(1: 1)$ planarmixed solar cells with and without the triclinic phase were studied. Increased short circuit current $\left(\mathrm{J}_{\mathrm{sc}}\right)$, fill factor $(\mathrm{FF})$, external quantum efficiency (EQE) and internal quantum efficiency (IQE) of the devices containing triclinic phase is attributed to the enhanced absorption in the near infrared (NIR) region and decreased series resistance. The correlation between open circuit voltage $\left(\mathrm{V}_{\mathrm{oc}}\right)$ and dark saturation pre-exponential factor $\left(\mathrm{J}_{\mathrm{so}}\right)$ was analyzed to investigate $\mathrm{V}_{\mathrm{oc}}$ loss upon annealing. The overall performance of device is considerably improved by introducing the triclinic phase of ClInPc.
\end{abstract}

\title{
Keywords:
}

Organic solar cells, non-planar Phthalocyanine, molecular aggregate phase

\section{Graphical abstract}
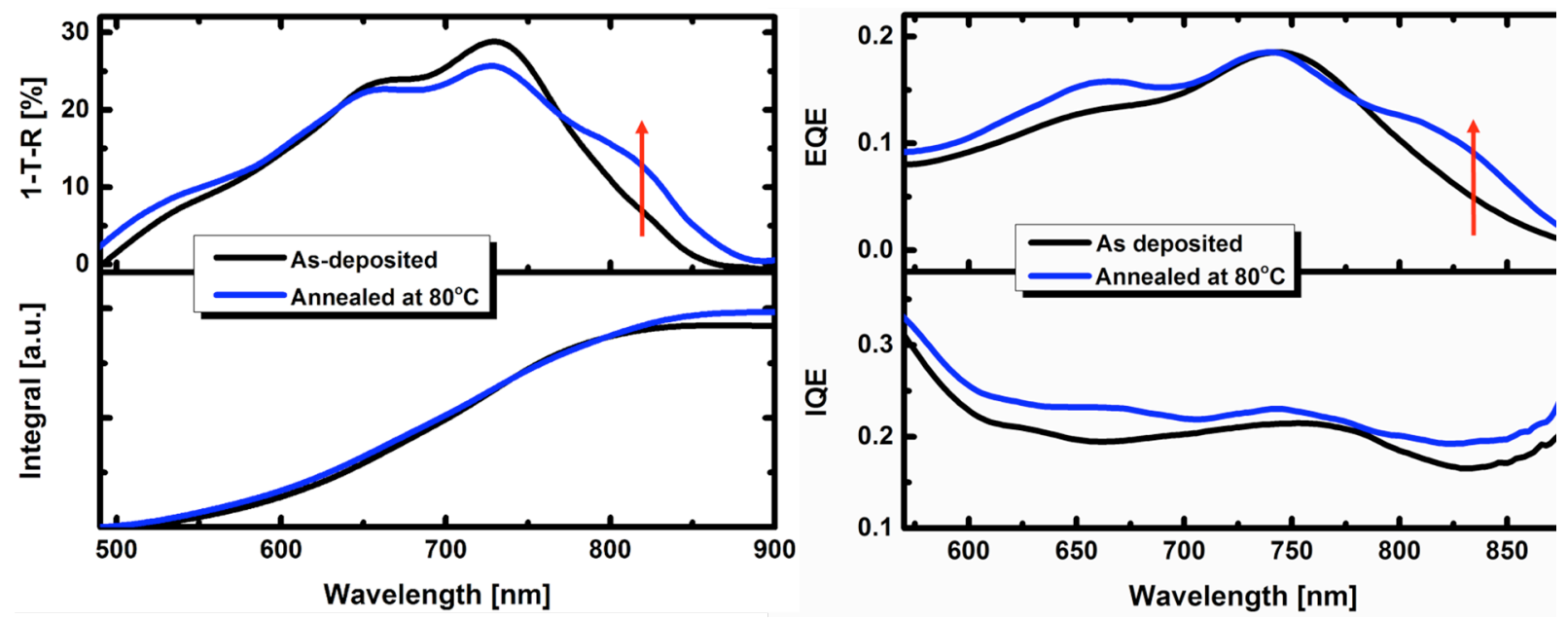


\section{Introduction}

The compatibility with low-cost materials and processing renders organic photovoltaics (OPVs) great potential to contribute to future energy needs ${ }^{1-2}$. However, although the power conversion efficiency of organic solar cells has steadily increased due to tremendous efforts in tuning molecular structure, morphology and device architecture ${ }^{3-8}$, the performance of OPVs requires further improvement for commercial application. One of the limiting factors is solar spectrum loss arising from narrow absorption range of each particular conjugated organic small molecule or polymer. One approach to this issue is to establish tandem devices by stacking subcells with photoactivity in different wavelength regions, thus ensuring wide spectrum coverage $^{9-12}$. Most organic solar cells underperform in the near infrared (NIR) wavelength region, which is a region of high solar photon flux, with $40 \%$ of the solar power being lost due to inefficient absorption in the NIR. Therefore, optimizing NIR absorption offers the opportunity to further increase the short circuit current of OPVs ${ }^{13-16}$.

Donor materials that have NIR response include donor-acceptor conjugated oligomers and polymers $^{9,}{ }^{17}$, carbon nanotubes ${ }^{18-19}$, and phthalocyanine $(\mathrm{Pc})$ materials $^{15,20-24}$. Various Pc materials are most frequently used due to their chemical tunability. Incorporating metal centers into Pc ring changes the shape of the molecule, which, in turn, tunes the morphology, crystallinity, and optical and electronic properties of the resulting films ${ }^{24}$. Divalent metals, such as $\mathrm{Cu}, \mathrm{Zn}, \mathrm{Co}$ and $\mathrm{Ni}$, give planar metal-Pc complexes, which form herringbone stacks in films. Two similar polymorphs, assigned as the $\alpha$ - and $\beta$-phase, are induced from two different intermolecular tilt angles within the herringbone stack ${ }^{25-26}$. The high similarity of the two phases gives rise to similar absorption features, with the most intense Q-band located between $500-750$ $\mathrm{nm}^{21,27}$. On the contrary, non-planar Pc materials, including PbPc, ClAlPc, TiOPc, VOPc and ClInPc, exhibit vastly different polymorphs, which are assigned as monoclinic phase and triclinic phase $^{28-30}$. Monoclinic form consists of molecules stacking in a face-to-face fashion, giving rise to metal ions in a linear chain ${ }^{28,31}$. Triclinic form consists of molecules stacking in a head-to-tail fashion, alternately orienting convex and concave $\operatorname{sides}^{28,32}$. The monoclinic form displays a blue-shifted absorption band compared to the monomer absorption, while the triclinic phase displays a red-shifted absorption band compared to the monomer ${ }^{22,33-36}$. In PbPc, for example, the absorption maximum of the triclinic form is at $900 \mathrm{~nm}$ while that of the monomer is at 690 $\mathrm{nm}^{23,33}$. Thus, the triclinic phase of non-planar Pc materials, in particular, renders them very interesting NIR absorbers for organic solar cells. Phase transformations between monoclinic and triclinic and/or mixtures of the two phases in thin films can be accessed by varying the deposition rate, tuning the substrate temperature during deposition, solvent annealing, or templating via a crystalline interlayer.

Tuning the organic film crystallinity, molecular orientation and aggregation by a templating layer toward better performance of organic solar cells has been drawing interest. The templating layers are focused on semiconducting organic molecules ${ }^{37-39}$ and copper halide. ${ }^{33,35,40-41}$ However, organic templating materials would cause competent light absorption, as well as additional interfacial energetics to be concidered. Copper halide is light sensitive and is detrimental to stability of organic materials. ${ }^{42}$ The aforementioned limitations evoke endeavors to investigate alternative strategies to achieve the same outcome.

In this work, we demonstrate that annealing a thin $(5 \mathrm{~nm})$ seed layer of ClInPc under mild conditions is a useful strategy to introduce the triclinic phase in subsequently deposited ClInPc 
film or ClInPc: $\mathrm{C}_{60}$ mixed films. Triclinic phase evolution was proved by morphology and absorption studies. Introducing the triclinic phase into $\mathrm{ClInPc}$ solar cells enhances device absorption and EQE beyond the $800 \mathrm{~nm}$ region and significantly increases IQE throughout the entire ClInPc photoactive region, which leads to increased $\mathrm{J}_{\mathrm{sc}}$, FF and power conversion efficiency (PCE) in both planar and planar-mixed solar cells. The loss of $\mathrm{V}_{\mathrm{oc}}$ with increasing triclinic phase was investigated and was explained by an increased dark saturation preexponential factor, $\mathrm{J}_{\mathrm{so}}$. The device performance is consistent with the previous study that adjacent molecules in triclinic phase have stronger $\pi-\pi$ interaction than those in monoclinic phase $^{34}$. On one hand, the stronger intermolecular interaction is responsible for the more delocalized electronic states ${ }^{34}$ favoring charge generation and collection. On the other hand, the stronger intermolecular interaction enhances recombination at donor/acceptor (D/A) interfaces leading to higher $\mathrm{J}_{\mathrm{so}}$. Hence, the molecular aggregate structure in non-planar phthalocyanine films needs to be carefully studied and engineered to fully utilize this NIR sensitive solar cell material.

\section{Materials and Methods}

ClInPc was purchased from Lumtec Corp., $\mathrm{MoO}_{3}, \mathrm{C}_{60}$ and $\mathrm{BCP}$ were purchased from SigmaAldrich Company. Organic thin films were grown on $10 \mathrm{~nm} \mathrm{MoO}_{3}$ pre-deposited on indium-tinoxide coated glass substrate (ITO/glass) in high vacuum $\left(<10^{-6}\right.$ Torr) at rate of $0.5 \AA / \mathrm{s}$, with the substrate maintained at room temperature during deposition. $\mathrm{ClInPc}_{6} \mathrm{C}_{60}(1: 1)$ blend films were prepared by co-deposition with both rates at $0.5 \AA / \mathrm{s}$. Annealing of $5 \mathrm{~nm}$ seed layer of ClInPc was conducted on a hot plate in $\mathrm{N}_{2}$ environment at $60^{\circ} \mathrm{C}, 80^{\circ} \mathrm{C}$ or $100^{\circ} \mathrm{C}$ for $15 \mathrm{~min} . \mathrm{MoO}_{3}$ and the subsequent organic layers were deposited without a mask, while the top $\mathrm{Ag}$ electrode was deposited with a metal mask to yield a final device area of $1.21 \mathrm{~mm}^{2}$.

The optical absorption was obtained by measuring the transmittance and reflectance of the ClInPc films on ITO/glass deposited with $10 \mathrm{~nm} \mathrm{MoO}_{3}$ using an Evolution $220 \mathrm{UV}-$ Visible Spectrophotometer with ISA 220 integrating sphere. The morphology of the films was characterized in air using an Agilent 5500 atomic force microscope (AFM). All devices related operation and measurement were performed in a nitrogen filled glovebox. Current-voltage characteristics of organic solar cells was measured under dark and simulated AM 1.5G solar illumination from a solar simulator with a Xe-arc lamp. A crystalline Si reference cell was used to measure the intensity of the solar simulator, which was adjusted to 1 sun.

\section{Results and Discussion}

\subsection{Film morphology}

First, we characterized the morphologies of a $5 \mathrm{~nm}$ seed layer of ClInPc as-deposited or annealed at different temperatures (shown in Figure 1). Figure 1a of bare ITO surface morphology shows clusters of tens of nanometers in diameter with root mean square (RMS) roughness of $1.23 \mathrm{~nm}$. A $5 \mathrm{~nm}$ ClInPc seed layer (Figure 1b-e) as-deposited or annealed covers the ITO cluster morphology, suggesting the presence of a continuous wetting layer. The asdeposited film is mostly uniform with sparsely distributed islands. RMS roughness of CIInPc films increases along with the annealing temperature, which is $2.2 \mathrm{~nm}$ for as-deposited film, 3.2 $\mathrm{nm}, 5.6 \mathrm{~nm}$ and $6.1 \mathrm{~nm}$ for films annealed at $60^{\circ} \mathrm{C}, 80^{\circ} \mathrm{C}$ or $100^{\circ} \mathrm{C}$, respectively. The roughness partially arises from the lateral growth of islands. To understand the vertical growth behavior of 
islands at different temperatures, the height density distribution was plotted in Figure 1f. The asdeposited CIInPc film exhibits a density maximum at $4.7 \mathrm{~nm}$, a shoulder at $5.8 \mathrm{~nm}$, and a tail extending to $10 \mathrm{~nm}$. Upon annealing, all density distributions are broadened, with the maxima shifting to $5.5 \mathrm{~nm}$. The distribution tail extends to $12 \mathrm{~nm}$ for the film annealed at $60^{\circ} \mathrm{C}$, and to 30 $\mathrm{nm}$ for the film annealed at $80^{\circ} \mathrm{C}$ or $100^{\circ} \mathrm{C}$. Therefore, we can conclude that larger size clusters evolve with higher annealing temperature.

Next, we investigated the morphologies of films with an additional $15 \mathrm{~nm}$ ClInPc grown on the aforementioned $5 \mathrm{~nm}$ seed layers (Figure 2a-d). Significant differences in film morphology were observed for films grown on seed layers annealed at $80^{\circ} \mathrm{C}$ and higher. The domain size of $\mathrm{ClInPc}$ fims also increased with increasing seed layer annealing temperature: RMS roughness of $15 \mathrm{~nm}$ ClInPc films grown on seed layers as-deposited or annealed at $60^{\circ} \mathrm{C}, 80^{\circ} \mathrm{C}$ or $100^{\circ} \mathrm{C}$ were $3.5 \mathrm{~nm}, 4.2 \mathrm{~nm}, 6.7 \mathrm{~nm}$ and $7.1 \mathrm{~nm}$ respectively.

Figure 2e-f shows surface morphology of CIInPc: $\mathrm{C}_{60}(1: 1)$ blend films used for planar-mixed solar cells. The films were prepared as follows: seed layer either as-deposited or annealed at $80^{\circ} \mathrm{C}$ was prepared on $\mathrm{MoO}_{3}$ covered ITO/glass. An additional $5 \mathrm{~nm}$ ClInPc and $10 \mathrm{~nm}$ ClInPc: $\mathrm{C}_{60}(1: 1)$ blend was subsequently deposited. The surface of a ClInPc: $\mathrm{C}_{60}(1: 1)$ blend film is smoother than that of neat ClInPc films. The RMS roughness of the blend film on the seed layer as-deposited is $1.2 \mathrm{~nm}$ and on the annealed seed layer is $5.6 \mathrm{~nm}$. The observed larger cluster size and higher RMS roughness of the CIInPc films and CIInPc: $\mathrm{C}_{60}(1: 1)$ blend films grown on the annealed seed layer suggest better crystallinity.

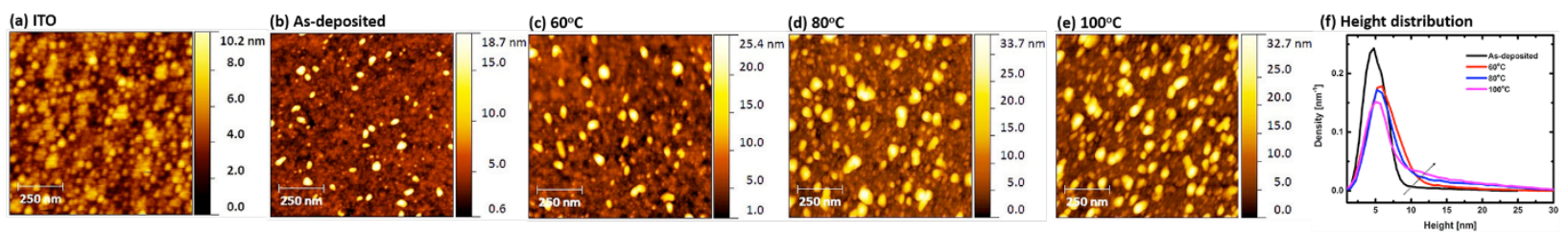

Figure 1. AFM topography images of (a) bare ITO, (b) $5 \mathrm{~nm}$ films of ClInPc seed layers as-deposited, (c) annealed at $60^{\circ} \mathrm{C}$, (d) $80^{\circ} \mathrm{C}$ and (e) $100^{\circ} \mathrm{C}$. (f) Shows the height distribution of images (b)-(e).

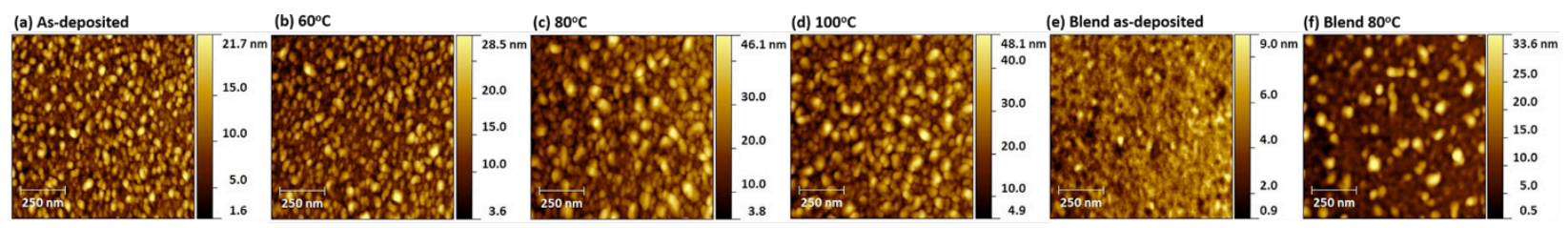

Figure 2. AFM topography images of (a) $15 \mathrm{~nm}$ film of ClInPc grown on seed layers as-deposited, (b) $15 \mathrm{~nm}$ film of ClInPc grown on seed layers annealed at $60^{\circ} \mathrm{C}$, (c) $80^{\circ} \mathrm{C}$, (d) and $100^{\circ} \mathrm{C}$. (e) ClInPc: $\mathrm{C}_{60}(1: 1)$ mixed film grown on $10 \mathrm{~nm}$ CIInPc film with first $5 \mathrm{~nm}$ as deposited and (f) annealed at $80^{\circ} \mathrm{C}$.

\subsection{Film absorption}

Figure 3a shows the absorption of $15 \mathrm{~nm}$ ClInPc film grown on $5 \mathrm{~nm}$ ClInPc seed layer. As was observed for non-planar phthalocyanine materials, PbPc, VOPc and TiOPc, the triclinic phase induces stronger $\pi-\pi$ interaction between adjacent Pc rings and causes broadening of the Q-band spectrum toward NIR. ${ }^{43-48}$ The reason for this broadening is the prevalent exciton coupling in the coordinated complex..$^{22,49}$ For the as-deposited film, the dominant peak at $730 \mathrm{~nm}$ can be assigned to the monoclinic phase of ClInPc. Upon annealing at $60^{\circ} \mathrm{C}$, a very weak shoulder evolves at $830 \mathrm{~nm}$, which can be assigned to the triclinic phase of ClInPc. Increasing 
absorption at $830 \mathrm{~nm}$, corresponding to an increasing concentration of the triclinic phase, is observed with increasing annealing temperature. Examining the integral of the total absorption spectra of these films, it is apparent that the integral of all $20 \mathrm{~nm}$ ClInPc film are identical at wavelengths below $800 \mathrm{~nm}$ but diverge above $800 \mathrm{~nm}$. The triclinic phase in films annealed at $80^{\circ} \mathrm{C}$ or $100^{\circ} \mathrm{C}$ significantly contribute to the total absorption.

To tease out whether the phase transformation occurs within the $5 \mathrm{~nm}$ seed layer or in the subsequently-deposited $15 \mathrm{~nm}$ film, the absorption of $5 \mathrm{~nm}$ seed layer as-deposited and annealed at $80^{\circ} \mathrm{C}$ was measured as shown in Figure $3 \mathrm{~b}$. For the as-deposited film, there is no shoulder at $830 \mathrm{~nm}$. The ratio of absorption at $830 \mathrm{~nm}$ and at $730 \mathrm{~nm}\left(\mathrm{~A}_{830} / \mathrm{A}_{730}\right)$ is 0.084 . For the annealed seed layer, $\mathrm{A}_{830} / \mathrm{A}_{730}$ is 0.17 , indicating triclinic phase formation in the seed layer. However, $\mathrm{A}_{830} / \mathrm{A}_{730}$ of the film with additional $15 \mathrm{~nm}$ film grown on seed layer annealed at $80^{\circ} \mathrm{C}$ is 0.40 , about 2.4 times higher than the value of the seed layer, suggesting that most of the triclinic phase is formed in the upper $15 \mathrm{~nm}$ film.

Figure $3 c$ shows the absorption spectra of the same planar-mixed films used for the morphological study in Figure 2e-f. A weak triclinic absorption appears in the bulk film grown on the as-deposited seed layer, with an $\mathrm{A}_{830} / \mathrm{A}_{730}$ value of 0.095 . Films grown on a seed layer annealed at $80^{\circ} \mathrm{C}$ display an increased $\mathrm{A}_{830} / \mathrm{A}_{730}$ ratio of 0.27 . Thus, the annealed seed layer also directs the formation of triclinic phase in ClInPc: $\mathrm{C}_{60}$ blend films.

(a)

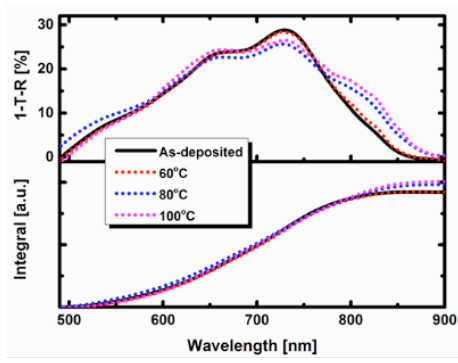

(b)

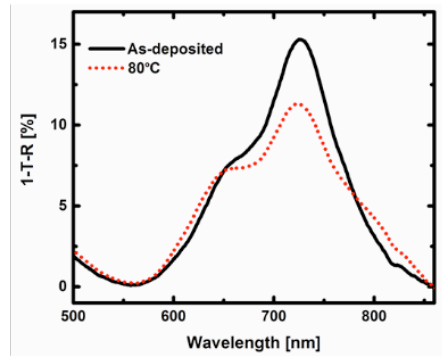

(c)

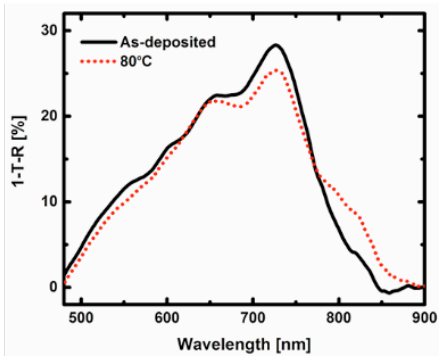

Figure 3. (a) Absorption spectra of $15 \mathrm{~nm}$ film of ClInPc grown on seed layers as-deposited or annealed and the integral of each spectrum. The measurement was taken under transmittance and reflectance mode respectively. The evolution of absorption above $800 \mathrm{~nm}$ of the films with annealed seed layer is attributed to the triclinic phase of ClInPc, which also contributes to the enhancement of total absorption. (b) Absorption spectra of $5 \mathrm{~nm}$ ClInPc seed layers as deposited or annealed at $80^{\circ} \mathrm{C}$. (c) Absorption spectra of ClInPc: $\mathrm{C}_{60}(1: 1)$ mixed film grown on a ClInPc seed layer as-deposited and annealed at $80^{\circ} \mathrm{C}$.

\subsection{Device performance}

Figure 4 shows the current density - voltage $(\mathrm{J}-\mathrm{V})$ characteristics under 1 sun $\left(100 \mathrm{~mW} / \mathrm{cm}^{2}\right)$ AM $1.5 \mathrm{G}$ illumination of planar heterojunction devices of the following structure: $\mathrm{ITO} / \mathrm{MoO} 3$ $(30 \mathrm{~nm}) / \mathrm{ClInPc}(5 \mathrm{~nm}$ seed $) / \mathrm{ClInPc}(15 \mathrm{~nm}) / \mathrm{C}_{60}(40 \mathrm{~nm}) / \mathrm{BCP}(10 \mathrm{~nm}) / \mathrm{Ag}(100 \mathrm{~nm})$. The first 5 $\mathrm{nm}$ ClInPc serves as a seed layer to control morphology of the additional $15 \mathrm{~nm} \mathrm{ClInPc}$. Observed performance parameters are summarized in Table 1. Devices with an annealed seed layer give better overall performance than devices with an as-deposited seed layer. PCE is gradually increased from $1.68 \%$ to $1.97 \%$ upon annealing. The greatest improvement is observed as the annealing temperature is increased from $60^{\circ} \mathrm{C}$ to $80^{\circ} \mathrm{C}$. Annealing at $100^{\circ} \mathrm{C}$ induces 
identical device performance as annealing at $80^{\circ} \mathrm{C}$. This increase in device performance is concomitant with the evolution of a triclinic phase within the ClInPc films. Figure 5 shows the dependencies of performance parameters on seed layer annealing conditions. Improvements in $\mathrm{J}_{\mathrm{sc}}$ and $\mathrm{FF}$ are observed upon annealing up to $80^{\circ} \mathrm{C}$, while $\mathrm{V}_{\text {oc }}$ decreases with annealing temperature. Overall, the highest PCE is obtained for seed layers annealed at $80^{\circ} \mathrm{C}$.

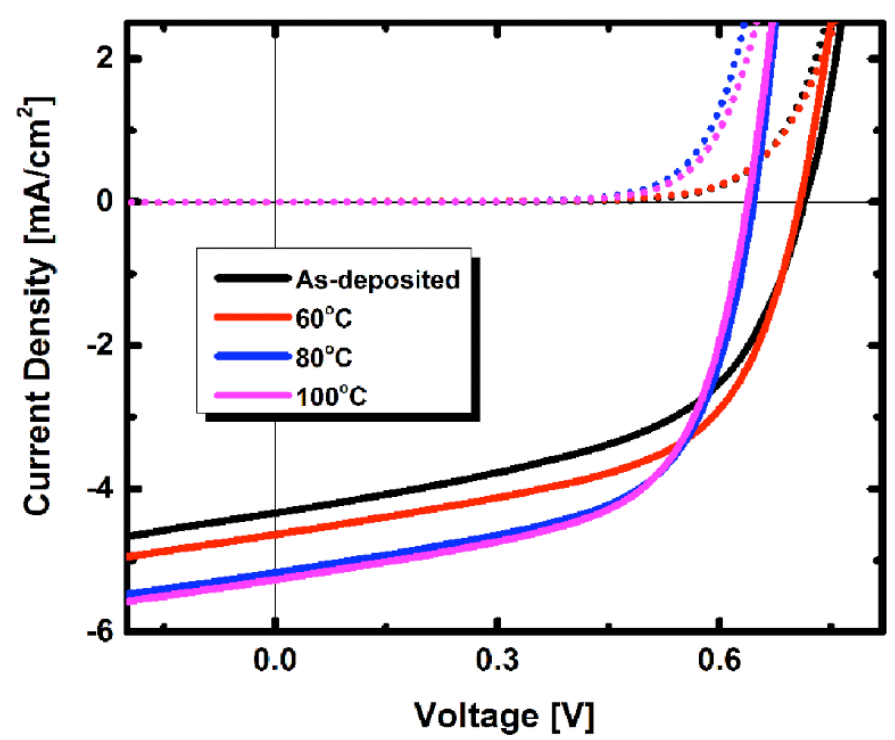

Figure 4. The $\mathrm{J}-\mathrm{V}$ characteristics of $\mathrm{ClInPc} / \mathrm{C}_{60}$ planar solar cells containing seed layer as deposited or annealed under 1 sun simulated AM $1.5 \mathrm{G}$ solar illumination.
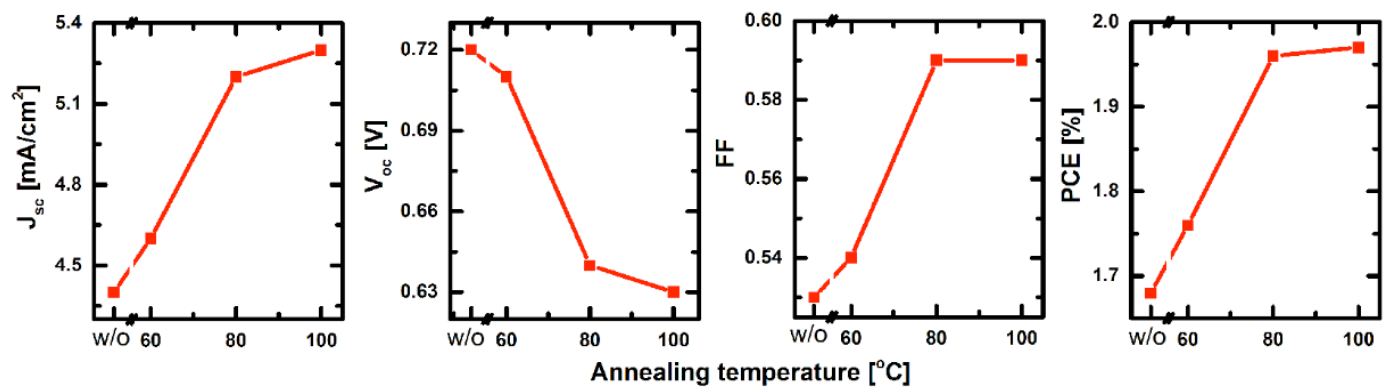

Figure 5. Comparison of the $\mathrm{ClInPc} / \mathrm{C}_{60}$ planar solar cell performance dependencies on the ClInPc seed layer annealing conditions.

Table 1. Solar cell performance parameters extracted from J-V characteristics in Figures 4 and 7.

\begin{tabular}{cccccc}
\hline \hline Planar & $100^{\circ} \mathrm{C}$ & 5.3 & 0.63 & 0.59 & 1.97 \\
Planar-mixed & As-deposited & 4.0 & 0.64 & 0.40 & 1.02 \\
Planar-mixed & $80^{\circ} \mathrm{C}$ & 5.5 & 0.59 & 0.57 & 1.85 \\
\hline \hline Planar & $80^{\circ} \mathrm{C}$ & 5.2 & 0.64 & 0.59 & 1.96 \\
\hline
\end{tabular}


Figure 6a shows the EQE and IQE spectra of the planar structure device with the seed layer as-deposited or annealed at $80^{\circ} \mathrm{C}$. Considering the comparison between the devices comprising the same materials, mismatch factor is not included. Enhancement of EQE at regions below 700 $\mathrm{nm}$ and between $800-900 \mathrm{~nm}$ contributes to the increase of $\mathrm{J}_{\mathrm{sc}}$ from $4.4 \mathrm{~mA} / \mathrm{cm}^{2}$ to $5.2 \mathrm{~mA} / \mathrm{cm}^{2}$. The increase at $800-900 \mathrm{~nm}$ corresponds to the increased triclinic phase absorption. Thus, transforming the ClInPc film from a monoclinic to triclinic phase leads to stronger absorption in the NIR region and enhances the EQE and PCE of solar cells.

IQE is also enhanced across the entire ClInPc photoactive region, suggesting improved charge collection due to morphological factors. One factor is the lower series resistance $\mathrm{R}_{\mathrm{s}}$ in the device containing triclinic phase. The $\mathrm{R}_{\mathrm{s}}$ of the device with seed layer as-deposited or annealed at $80^{\circ} \mathrm{C}$ is $22.99 \Omega \mathrm{cm}^{2}$ and $14.99 \Omega \mathrm{cm}^{2}$, respectively, as shown in Table 2 . The reduced $\mathrm{R}_{\mathrm{s}}$ presumably induces FF improvement as shown in Table 1 . The reduced $\mathrm{R}_{\mathrm{s}}$ arises because the stronger selfexchange coupling interaction ${ }^{50-52}$ between the adjacent molecules in the triclinic phase leads to more efficient charge transport. Another reason that may contribute to increased IQE is the more delocalized electronic states ${ }^{34}$ introduced by triclinic phase, which essentially benefits exciton diffusion length and exciton dissociation efficiency. Photoluminescence (PL) based exciton diffusion length study is not included in this work due to the unavailability of CIInPc PL signal. It is because ClInPc has the favorable combination of high dipole moments associated respectively with paramagnetism and the presence of a central heavy metal, which leads to an intersystem crossing in 300 ps with a quantum yield close to unity. ${ }^{53}$ Hence, we studied the exciton diffusion length in the $\mathrm{ClInPc} / \mathrm{C}_{60}$ planar solar cells with seed layer with or without annealing. The results are shown in Figure $6 \mathrm{~b}$. The solid square dots are the experimental IQE values of the devices with the ClInPc thicknesses of 2, 5, 7, 15 and $20 \mathrm{~nm}$. The J-V characteristics of the corresponding devices are shown in Figure S1, and their EQE and 1Reflectance values are shown in Figure S2. The solid lines are the fitting curves following 1D diffusion equation:

$\mathrm{IQE}=\left(\mathrm{L}_{\mathrm{d}} / \mathrm{t}\right) \times\left(1-\exp \left(-2 \mathrm{t} / \mathrm{L}_{\mathrm{d}}\right)\right) /\left(1+\exp \left(-2 \mathrm{t} / \mathrm{L}_{\mathrm{d}}\right)\right)$

Where $L_{d}$ is the exciton diffusion length, $t$ is CIInPc film thickness and IQE is thickness dependent internal quantum efficiency. ${ }^{48,49}$ To fit the experimental IQE-t data, a value of $\mathrm{L}_{\mathrm{d}}=$ $2.4 \mathrm{~nm}$ is applied for the device with an as-deposited seed layer, and a value of $L_{d}=2.9 \mathrm{~nm}$ is applied for the device with a seed layer annealed at $80^{\circ} \mathrm{C}$. Therefore, a slightly increased exciton diffusing length is observed in the triclinic phase enriched device. 
(a)

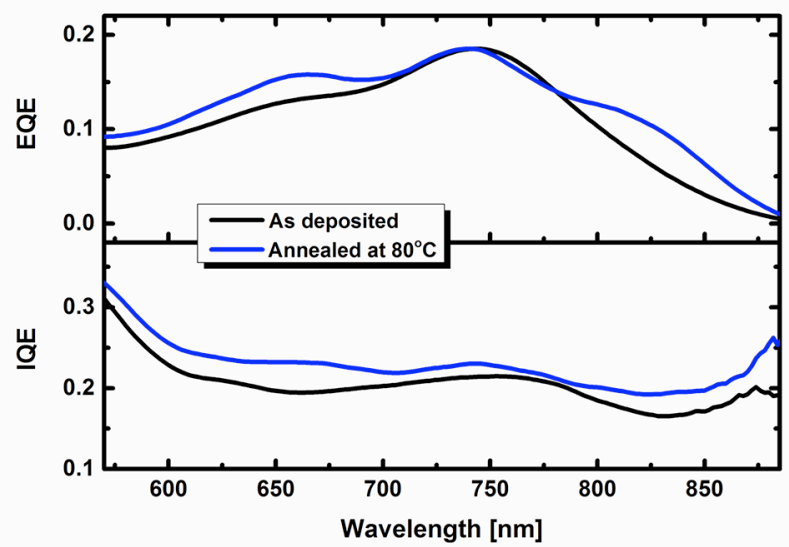

(b)

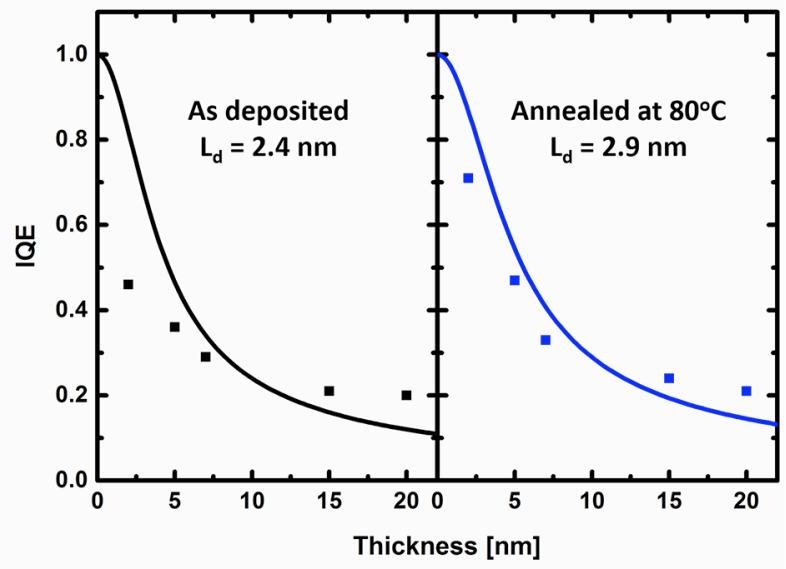

Figure 6. (a) The EQE and IQE spectra of the planar structure devices containing seed layers as-deposited or annealed at $80^{\circ} \mathrm{C}$. (b) The thickness dependent experimental IQE values (solid square dots) and fitted 1D diffusion equation curve (equation 1 ).

An increased concentration of the triclinic phase in ClInPc films is accompanied by a photovoltage loss in devices. Several possible reasons can cause $\mathrm{V}_{\mathrm{oc}}$ loss. Lower $\Delta \mathrm{E}_{\mathrm{DA}}$ (energy difference between the highest occupied molecular orbital (HOMO) of the donor and the lowest unoccupied molecular orbital (LUMO) of the acceptor) at triclinic phase $\mathrm{ClInPc} / \mathrm{C}_{60}$ interface compared to the monoclinic phase $\mathrm{ClInPc} / \mathrm{C}_{60}$ interface could possibly contribute to $\mathrm{V}_{\text {oc }}$ loss, since the HOMO of the triclinic phase is shallower than that of the monoclinic phase ${ }^{54}$. Other possible reasons include the roughness introduced by the triclinic phase as discussed above and studied elsewhere, or heating-induced nonuniformity in organic films.

Here we examine the effect of the triclinic phase on the dark saturation current pre-exponential factor, which essentially determines $\mathrm{V}_{\mathrm{oc}}{ }^{50-51}$. Dependence of Voc on the dark saturation current is revealed by equation 2 :

Voc $\approx$ nkTqlnJscJs 
where $\mathrm{n}$ is diode ideality factor, $\mathrm{k}$ is the Boltzmann constant, and $\mathrm{q}$ is elementary charge. The dark saturation current $\left(J_{\mathrm{s}}\right)$ is dominated by recombination $(\mathrm{n} \approx 2)$ and can be represented by equation 3:

$$
\mathrm{Js}=\mathrm{J} \operatorname{soexp}(-\Delta \mathrm{EDA} 2 \mathrm{nkT})
$$

Combining equations (2) and (3) yields

$$
\text { Voc }=(\text { nkTq }) \ln (\text { JscJso })+\Delta \mathrm{EDA} 2 \mathrm{q}
$$

The pre-exponential factor is a measure of ratio of charge generation to recombination. Extracted $\mathrm{n}, \mathrm{J}_{\mathrm{s}}$ and $\mathrm{J}_{\mathrm{so}}$ values for devices containing seed layers as-deposited or annealed at $80^{\circ} \mathrm{C}$ are listed in Table 2. $\Delta \mathrm{E}_{\mathrm{DA}}$ is $1.3 \mathrm{eV}$ for ClInPc/ $\mathrm{C}_{60}$ heterojunction based on HOMO of ClInPc $5.3 \mathrm{eV}^{20}$ and LUMO of $\mathrm{C}_{60} 4.0 \mathrm{eV}^{55} . \mathrm{J}_{\mathrm{so}}$ is $0.19 \mathrm{~mA} / \mathrm{cm}^{2}$ for the device with as-deposited seed layer and $0.49 \mathrm{~mA} / \mathrm{cm}^{2}$ for the device with seed-layer annealed at $80^{\circ} \mathrm{C}$. The magnitude of $\mathrm{J}_{\mathrm{so}}$ is often affected by the intermolecular reorganization energy for electron transfer from the donor to the acceptor, the electrical conductivity of organic films, the density of relevant states at D/A interface and the strength of coupling between the donor and acceptor material. Since stronger $\pi$ interaction between adjacent $\mathrm{ClInPc}$ molecules in the triclinic phase compared to the monoclinic phase has been studied, it is possible that the same enhanced interaction at ClInPc and $\mathrm{C}_{60}$ interface exists and facilitates bimolecular recombination, which leads to increased $\mathrm{J}_{\mathrm{so}}$. The calculated $\mathrm{V}_{\mathrm{oc}}$ in Table 2 is derived by solving Eq. (4), where we assume $\triangle \mathrm{EDA}$ is the same for both devices. As a result, the difference between the calculated $\mathrm{V}_{\mathrm{oc}}$ is identical to that of the measured $V_{o c}$, suggesting $V_{o c}$ loss upon annealing is derived from the first item of Eq. (4), in other words, from $\mathrm{J}_{\mathrm{so}}$. Therefore, the tradeoff between enhanced charge generation and collection and simultaneously increased recombination derived from stronger intermolecular or interfacial interaction of triclinic phase should be carefully considered when engineering non-planar phthalocyanine solar cells.

To investigate if an annealed seed layer improves the performance of bulk heterojuction solar cells, planar-mixed solar cells were fabricated. The structure is ITO/ $\mathrm{MoO}_{3}(10 \mathrm{~nm}) / \mathrm{ClInPc}(10$ $\mathrm{nm}) / \mathrm{ClInPc}: \mathrm{C}_{60}(1: 1)(10 \mathrm{~nm}) / \mathrm{C}_{60}(20 \mathrm{~nm}) / \mathrm{BCP}(10 \mathrm{~nm}) / \mathrm{Ag}(100 \mathrm{~nm})$, in which the first $5 \mathrm{~nm}$ of $\mathrm{ClInPc}$ is seed layer, either as-deposited or annealed at $80^{\circ} \mathrm{C}$. As discussed above, the presence of the triclinic phase was revealed by the absorption spectrum (Figure 3c). Figure 7 shows the J-V characteristics of the planar-mixed solar cell. The device performance parameters are included in Table 1. $\mathrm{J}_{\mathrm{sc}}$ is increased from 4.0 to $5.5 \mathrm{~mA} / \mathrm{cm}^{2}$. For the device with as-deposited seed layer, all $\mathrm{J}_{\mathrm{sc}}, \mathrm{V}_{\mathrm{oc}}$ and $\mathrm{FF}$ values are lower than planar structure, largely due to prevalent bimolecular recombination as the donor-acceptor interface is increased. With an annealed seed layer, triclinic phase in bulk heterojunction helps increase exciton delocalization leading to increased charge collection. As a result, $\mathrm{J}_{\mathrm{sc}}$ is increased from $4.0 \mathrm{~mA} / \mathrm{cm}^{2}$ to $5.5 \mathrm{~mA} / \mathrm{cm}^{2}$, FF is increased from 0.40 to $0.57, \mathrm{~V}_{\mathrm{oc}}$ also shows decrease from $0.64 \mathrm{~V}$ to $0.59 \mathrm{~V}$, and PCE exhibits a $69 \%$ increase. Thus we suggest that for non-planar phthalocyanine NIR absorbing solar cells, utilizing a seed layer to control the morphology of entire photoactive layer not only is applicable for planar architecture solar cell, but also can be a useful strategy for planar-mixed solar cell. 


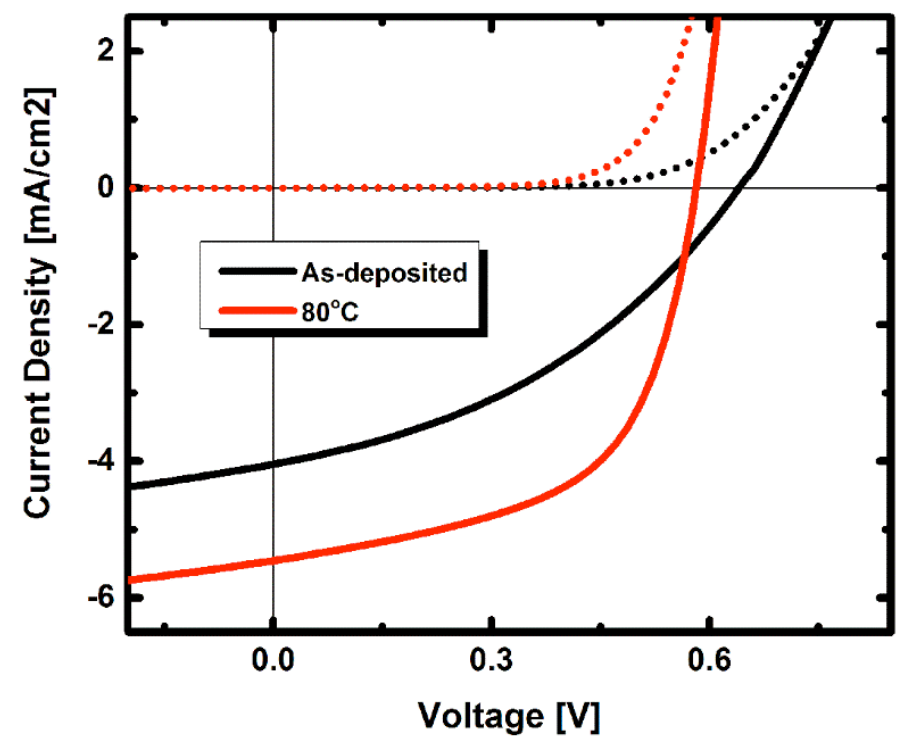

Figure 7. The $\mathrm{J}-\mathrm{V}$ characteristics of ClInPc/ClInPc: $\mathrm{C}_{60} / \mathrm{C}_{60}$ planar-mixed solar cells containing seed layer as deposited or annealed at $80^{\circ} \mathrm{C}$ under 1 sun simulated $\mathrm{AM} 1.5 \mathrm{G}$ solar illumination.

Table 2. The relevant numbers from $\mathrm{J}-\mathrm{V}$ characteristics of $\mathrm{ClInPc} / \mathrm{C}_{60}$ planar solar cell with seed layer as-deposited or annealed at $80^{\circ} \mathrm{C}$ in Figure 4 and Table 1. Calculated $\mathrm{V}_{\text {oc }}$ is taken from solving Eq. (4).

\begin{tabular}{ccccccc}
\hline \hline $\begin{array}{c}\text { Annealing } \\
\text { Condition }\end{array}$ & $\begin{array}{c}\mathrm{R}_{\mathrm{s}} \\
\left(\Omega \mathrm{cm}^{2}\right)\end{array}$ & $\mathrm{n}$ & $\begin{array}{c}\mathrm{J}_{\mathrm{s}} \\
\left(\mathrm{mA} / \mathrm{cm}^{2}\right)\end{array}$ & $\begin{array}{c}\mathrm{J}_{\mathrm{so}} \\
\left(\mathrm{mA} / \mathrm{cm}^{2}\right)\end{array}$ & $\begin{array}{c}\text { Obs. } \mathrm{V}_{\mathrm{oc}} \\
(\mathrm{V})\end{array}$ & $\begin{array}{c}\text { Calc. } \mathrm{V}_{\mathrm{oc}} \\
(\mathrm{V})\end{array}$ \\
\hline As-deposited & 22.99 & 2.28 & $3.45 \times 10^{-3}$ & 0.19 & 0.72 & 0.83 \\
$80^{\circ} \mathrm{C}$ & 14.99 & 2.06 & $2.61 \times 10^{-3}$ & 0.49 & 0.64 & 0.77 \\
\hline \hline
\end{tabular}

\section{Conclusions}

The morphologies of ClInPc neat films and ClInPc: $\mathrm{C}_{60}$ mixed films were effectively controlled using a pre-deposited ClInPc seed layer. The triclinic phase of ClInPc is enriched in films grown on annealed seed layers, as revealed by the evolution of a red-shifted absorption shoulder compared to the monoclinic phase absorption. The same ClInPc neat films and CIInPc: $\mathrm{C}_{60}$ mixed films were incorporated into planar and planar-mixed solar cells. A correlation between triclinic phase content and increased $\mathrm{J}_{\mathrm{sc}}, \mathrm{FF}$ and PCE, as well as reduced $\mathrm{V}_{\text {oc }}$ was observed. Increased $\mathrm{J}_{\mathrm{sc}}, \mathrm{FF}, \mathrm{EQE}$ and IQE is attributed to the enhanced absorption at NIR region and reduced series resistance in the triclinic phase-containing films. Decreased $V_{\text {oc }}$ is correlated to the higher $\mathrm{J}_{\mathrm{so}}$. Both reduced series resistance and increased $\mathrm{J}_{\mathrm{so}}$ are derived from stronger intermolecular interaction (at donor/donor or donor/acceptor interface) in the triclinic form compared to the monoclinic form.

\section{Acknowledgments}

The authors gratefully acknowledge financial support from the Air Force Office of Scientific Research (Grant number FA9550-14-1-0128). 


\section{References}

1. Spanggaard, H.; Krebs, F. C., A brief history of the development of organic and polymeric photovoltaics. Solar Energy Materials and Solar Cells 2004, 83 (2-3), 125-146.

2. Krebs, F. C.; Gevorgyan, S. A.; Gholamkhass, B.; Holdcroft, S.; Schlenker, C.; Thompson, M. E.; Thompson, B. C.; Olson, D.; Ginley, D. S.; Shaheen, S. E.; Alshareef, H. N.; Murphy, J. W.; Youngblood, W. J.; Heston, N. C.; Reynolds, J. R.; Jia, S.; Laird, D.; Tuladhar, S. M.; Dane, J. G. A.; Atienzar, P.; Nelson, J.; Kroon, J. M.; Wienk, M. M.; Janssen, R. A. J.; Tvingstedt, K.; Zhang, F.; Andersson, M.; Inganäs, O.; LiraCantu, M.; de Bettignies, R.; Guillerez, S.; Aernouts, T.; Cheyns, D.; Lutsen, L.; Zimmermann, B.; Würfel, U.; Niggemann, M.; Schleiermacher, H.-F.; Liska, P.; Grätzel, M.; Lianos, P.; Katz, E. A.; Lohwasser, W.; Jannon, B., A round robin study of flexible large-area roll-to-roll processed polymer solar cell modules. Solar Energy Materials and Solar Cells 2009, 93 (11), 1968-1977.

3. Brabec, C. J.; Gowrisanker, S.; Halls, J. J.; Laird, D.; Jia, S.; Williams, S. P., Polymer-fullerene bulkheterojunction solar cells. Adv Mater 2010, 22 (34), 3839-56.

4. Steim, R.; Kogler, F. R.; Brabec, C. J., Interface materials for organic solar cells. J Mater Chem 2010, 20 (13), 2499-2512.

5. Heremans, P.; Cheyns, D.; Rand, B. P., Strategies for Increasing the Efficiency of Heterojunction Organic Solar Cells: Material Selection and Device Architecture. Accounts of Chemical Research 2009, 42 (11), 1740-1747.

6. Hains, A. W.; Liang, Z.; Woodhouse, M. A.; Gregg, B. A., Molecular Semiconductors in Organic Photovoltaic Cells. Chemical reviews 2010, 110 (11), 6689-6735.

7. Thompson, B. C.; Fréchet, J. M. J., Polymer-Fullerene Composite Solar Cells. Angewandte Chemie International Edition 2008, 47 (1), 58-77.

8. Brédas, J.-L.; Norton, J. E.; Cornil, J.; Coropceanu, V., Molecular Understanding of Organic Solar Cells: The Challenges. Accounts of Chemical Research 2009, 42 (11), 1691-1699.

9. You, J.; Dou, L.; Yoshimura, K.; Kato, T.; Ohya, K.; Moriarty, T.; Emery, K.; Chen, C.-C.; Gao, J.; Li, G.; Yang, Y., A polymer tandem solar cell with $10.6 \%$ power conversion efficiency. Nature communications 2013, 4, 1446.

10. Ameri, T.; Li, N.; Brabec, C. J., Highly efficient organic tandem solar cells: a follow up review. Energy \& Environmental Science 2013, 6 (8), 2390-2413.

11. Che, X.; Xiao, X.; Zimmerman, J. D.; Fan, D.; Forrest, S. R., High-Efficiency, Vacuum-Deposited, Small-Molecule Organic Tandem and Triple-Junction Photovoltaic Cells. Advanced Energy Materials 2014, 4 (18), n/a-n/a.

12. Riede, M.; Uhrich, C.; Widmer, J.; Timmreck, R.; Wynands, D.; Schwartz, G.; Gnehr, W.-M.; Hildebrandt, D.; Weiss, A.; Hwang, J.; Sundarraj, S.; Erk, P.; Pfeiffer, M.; Leo, K., Efficient Organic Tandem Solar Cells based on Small Molecules. Advanced Functional Materials 2011, 21 (16), 3019-3028.

13. Perez, M. D.; Borek, C.; Djurovich, P. I.; Mayo, E. I.; Lunt, R. R.; Forrest, S. R.; Thompson, M. E., Organic Photovoltaics Using Tetraphenylbenzoporphyrin Complexes as Donor Layers. Advanced Materials 2009, 21 (14-15), 1517-1520.

14. Rand, B. P.; Xue, J.; Yang, F.; Forrest, S. R., Organic solar cells with sensitivity extending into the near infrared. Applied Physics Letters 2005, 87 (23), 233508.

15. Bailey-Salzman, R. F.; Rand, B. P.; Forrest, S. R., Near-infrared sensitive small molecule organic photovoltaic cells based on chloroaluminum phthalocyanine. Applied Physics Letters 2007, 91 (1), 013508.

16. Chauhan, K. V.; Sullivan, P.; Yang, J. L.; Jones, T. S., Efficient Organic Photovoltaic Cells through Structural Modification of Chloroaluminum Phthalocyanine/Fullerene Heterojunctions. The Journal of Physical Chemistry C 2010, 114 (7), 3304-3308. 
17. Huang, P.; Du J.; Gunathilake, S. S.; Rainbolt, E. A.; Murphy, J. W.; Black, K. T.; Barrera, D.; Hsu, J. P.; Gnade, B. E.; Stefan M. C.; Biewer, M. C., Benzodifuran and benzodithiophene donor-acceptor polymers for bulk heterojunction solar cells. Journal of Materials Chemistry A 2015, 3, 6980-6989.

18. Shea, M. J.; Arnold, M. S., $1 \%$ solar cells derived from ultrathin carbon nanotube photoabsorbing films. Applied Physics Letters 2013, 102 (24), 243101.

19. Wu, M.-Y.; Jacobberger, R. M.; Arnold, M. S., Design length scales for carbon nanotube photoabsorber based photovoltaic materials and devices. Journal of Applied Physics 2013, 113 (20), 204504.

20. Armstrong2, W. W. a. N., Doping Effect on Chloroindium Phthalocyanine (ClInPc)/C60 Solar Cells. Mater. Res. Soc. Symp. Proc. 2012.

21. Fleetham, T. B.; Mudrick, J. P.; Cao, W.; Klimes, K.; Xue, J.; Li, J., Efficient zinc phthalocyanine/C60 heterojunction photovoltaic devices employing tetracene anode interfacial layers. ACS Appl Mater Interfaces 2014, 6 (10), 7254-9.

22. Hiramoto, M.; Kitada, K.; Iketaki, K.; Kaji, T., Near infrared light driven organic p-i-n solar cells incorporating phthalocyanine J-aggregate. Applied Physics Letters 2011, 98 (2), 023302.

23. Kim, T.-M.; Kim, H. J.; Shim, H.-S.; Choi, M.-S.; Kim, J. W.; Kim, J.-J., The epitaxial growth of lead phthalocyanine on copper halogen compounds as the origin of templating effects. Journal of Materials Chemistry A 2014, 2 (23), 8730.

24. Claessens, C. G.; Hahn, U.; Torres, T., Phthalocyanines: from outstanding electronic properties to emerging applications. Chemical record 2008, 8 (2), 75-97.

25. Heutz, S.; Bayliss, S. M.; Middleton, R. L.; Rumbles, G.; Jones, T. S., Polymorphism in Phthalocyanine Thin Films: Mechanism of the $\alpha \rightarrow \beta$ Transition. The Journal of Physical Chemistry $B$ 2000, 104 (30), 7124-7129.

26. Achar, B. N.; Lokesh, K. S., Studies on polymorphic modifications of copper phthalocyanine. Journal of Solid State Chemistry 2004, 177 (6), 1987-1993.

27. Ren, J.; Meng, S.; Kaxiras, E., Theoretical investigation of the C60/copper phthalocyanine organic photovoltaic heterojunction. Nano Research 2012, 5 (4), 248-257.

28. Wim Dexters, E. B., Milos Nesladek, Jan D'Haen,Etienne Goovaertsc and Ken Haenen, Molecular orientation of lead phthalocyanine on (100) oriented single crystal diamond surfaces. Phys.Chem.Chem.Phys. 2015, 17, 9619.

29. Frank Herbstein, R. M., Changes in Space and Laue Groups of Some Published Crystal Structures. Acta Cryst. 1982, B38, 1051.

30. J. Mizuguchi, G. R., H. R. Karfunkel, Solid-state Spectra of Titanylphthalocyanine As Viewed from Molecular Distortion. J. Phys. Chem. A 1995, 99, 16217.

31. Ukei, K., Lead phthalocyanine. Acta Crystallographica Section B 1973, 29 (10), 2290-2292.

32. Iyechika, Y.; Yakushi, K.; Ikemoto, I.; Kuroda, H., Structure of lead phthalocyanine (triclinic form). Acta Crystallographica Section B 1982, 38 (3), 766-770.

33. Kim, T. M.; Shim, H. S.; Choi, M. S.; Kim, H. J.; Kim, J. J., Multilayer epitaxial growth of lead phthalocyanine and $\mathrm{C}(70)$ using $\mathrm{CuBr}$ as a templating layer for enhancing the efficiency of organic photovoltaic cells. ACS Appl Mater Interfaces 2014, 6 (6), 4286-91.

34. Varughese, S., Non-covalent routes to tune the optical properties of molecular materials. Journal of Materials Chemistry C 2014, 2 (18), 3499.

35. Vasseur, K.; Broch, K.; Ayzner, A. L.; Rand, B. P.; Cheyns, D.; Frank, C.; Schreiber, F.; Toney, M. F.; Froyen, L.; Heremans, P., Controlling the texture and crystallinity of evaporated lead phthalocyanine thin films for near-infrared sensitive solar cells. ACS Appl Mater Interfaces 2013, 5 (17), 8505-15.

36. Zawadzka, A.; Płóciennik, P.; Czarnecka, I.; Sztupecka, J.; Łukasiak, Z., The effects of annealing process influence on optical properties and the molecular orientation of selected organometallic compounds thin films. Optical Materials 2012, 34 (10), 1686-1691. 
37. K. V. Chauhan, P. S., J. L. Yang, T. S. Jones, Efficient Organic Photovoltaic Cells through Structural Modification of Chloroaluminum Phthalocyanine/Fullerene Heterojunctions. J. Phys. Chem. C 2010, 114, 3304.

38. Duan, H.; Yang, J.; Fu, L.; Xiong, J.; Yang, B.; Ouyang, J.; Zhou, C.; Huang, H.; Gao, Y., Interface modification of organic photovoltaics by combining molybdenum oxide (MoOx) and molecular template layer. Thin Solid Films 2015, 574, 146-151.

39. Soo Yook, K.; Doo Chin, B.; Yeob Lee, J.; Lassiter, B. E.; Forrest, S. R., Vertical orientation of copper phthalocyanine in organic solar cells using a small molecular weight organic templating layer. Applied Physics Letters 2011, 99 (4), 043308.

40. Shim, H.-S.; Kim, H. J.; Kim, J. W.; Kim, S.-Y.; Jeong, W.-I.; Kim, T.-M.; Kim, J.-J., Enhancement of near-infrared absorption with high fill factor in lead phthalocyanine-based organic solar cells. $J$ Mater Chem 2012, 22 (18), 9077.

41. Ngongang Ndjawa, G. O.; Graham, K. R.; Li, R.; Conron, S. M.; Erwin, P.; Chou, K. W.; Burkhard, G. F.; Zhao, K.; Hoke, E. T.; Thompson, M. E.; McGehee, M. D.; Amassian, A., Impact of Molecular Orientation and Spontaneous Interfacial Mixing on the Performance of Organic Solar Cells. Chemistry of Materials 2015, 27 (16), 5597-5604.

42. Lim, X., The slow-chemistry movement. Nature 2015, 524.

43. Miyamoto, A.; Nichogi, K.; Taomoto, A.; Nambu, T.; Murakami, M., Structural Control of Evaporated Lead-Phthalocyanine films, Thin Solid Films, 1995, 256, 64-67.

44. Basova, T. V.; Kiselev, V. G.; Dubkov, I. S.; Latteyer, F.; Gromilov, S. A.; Peisert, H.; Chassè, T., Optical Spectroscopy and XRD Study of Molecular Orientation, Polymorphism, and Phase Transitions in Fluorinated Vanadyl Phthalocyanine Thin Films. The Journal of Physical Chemistry C 2013, 117 (14), 7097-7106.

45. Vasseur, K.; Rand, B. P.; Cheyns, D.; Temst, K.; Froyen, L.; Heremans, P., Correlating the Polymorphism of Titanyl Phthalocyanine Thin Films with Solar Cell Performance. The Journal of Physical Chemistry Letters 2012, 3 (17), 2395-2400.

46. Placencia, D.; Wang, W.; Gantz, J.; Jenkins, J. L.; Armstrong, N. R., Highly Photoactive Titanyl Phthalocyanine Polymorphs as Textured Donor Layers in Organic Solar Cells. The Journal of Physical Chemistry C 2011, 115 (38), 18873-18884.

47. Placencia, D.; Wang, W.; Shallcross, R. C.; Nebesny, K. W.; Brumbach, M.; Armstrong, N. R., Organic Photovoltaic Cells Based On Solvent-Annealed, Textured Titanyl Phthalocyanine/C60Heterojunctions. Advanced Functional Materials 2009, 19 (12), 1913-1921.

48. Ortí, E.; Brédas, J. L.; Clarisse, C., Electronic structure of phthalocyanines: Theoretical investigation of the optical properties of phthalocyanine monomers, dimers, and crystals. The Journal of chemical physics 1990, 92 (2), 1228.

49. Telfer, S. G.; McLean, T. M.; Waterland, M. R., Exciton coupling in coordination compounds. Dalton transactions 2011, 40 (13), 3097-108.

50. Erwin, P.; Thompson, M. E., Elucidating the interplay between dark current coupling and open circuit voltage in organic photovoltaics. Applied Physics Letters 2011, 98 (22), 223305.

51. Perez, M. D.; Borek, C.; Forrest, S. R.; Thompson, M. E., Molecular and Morphological Influences on the Open Circuit Voltages of Organic Photovoltaic Devices. Journal of the American Chemical Society 2009, 131 (26), 9281-9286.

52. Schlenker, C. W.; Thompson, M. E., The molecular nature of photovoltage losses in organic solar cells. Chemical Communications 2011, 47 (13), 3702-3716.

53. James S. Shirk, R. G. S. P., Steven R. Flom, Heino Heckmann, and Michael Hanack, Effect of Axial Substitution on the Optical Limiting Properties of Indium Phthalocyanines. J. Phys. Chem. A 104.

54. Akira J. Ikushima, T. K., Shuji Yoshida, Akihiro Maeda Valence and conduction band edges of metal-phthalocyanines and carrier behavior. Thin Solid Films 1996, 273, 35. 
55. Peng, Y.; Zhang, L.; Andrew, T. L., High open-circuit voltage, high fill factor single-junction organic solar cells. Applied Physics Letters 2014, 105 (8), 083304. 